\title{
Additions to the Swedish myxomycete biota
}

\author{
UNO H. ELIASSON and ELISABETH GILERT
}

ELIASSON, U. H. \& GILERT, E. 2007: Additions to the Swedish myxomycete biota. - Karstenia 47: 0-0. Helsinki. ISSN 0453-3402.

\begin{abstract}
The current inventory of myxomycetes within the frames of the Swedish Taxonomy Initiative project continues to yield records of species not previously known to Sweden. A selection of twenty species here formally reported for the first time gives a total of 210 species so far known from Sweden. Among notable records are Echinostelium bisporum and E. lunatum, the two smallest species of myxomycetes known, fruitbodies of the first species rarely exceeding $25 \mu \mathrm{m}$ in height. Both species are impossible to detect using standard methods for myxomycetes and are probably far more common than the few widely scattered records in the world so far would suggest. Paradiacheopsis longipes is reported for the third time, previously known only from the Netherlands and China. Additional records are awaiting publication, but the delimitation and circumscription of several taxa require further study. Continued field-work supplemented with so-called moist chamber cultures will further increase the number of species known to occur in Sweden. Distribution patterns of myxomycetes are discussed briefly.
\end{abstract}

Key words: Swedish myxomycetes, Swedish Taxonomy Initiative, Myxomycete distribution, Arcyria, Echinostelium bisporum, Echinostelium lunatum, Paradiacheopsis longipes.

Uno H. Eliasson, Department of Plant and Environmental Sciences, Göteborg University, Box 461, SE 40530 Göteborg, Sweden / uno.eliasson@dpes.gu.se

Elisabeth Gilert, same address / elisabeth.gilert@dpes.gu.se

\section{Introduction}

Records of myxomycetes in Sweden date back to long before the true nature of these organisms was known. Although Linnaeus paid little attention to lower cryptogams there are three specific Linnaean epithets still in current use. The epithets are all applied to common and conspicuous species, namely Lycogala epidendrum (L.) Fries, Arcyria denudata (L.) Wettst. and Diderma radiatum (L.) Morgan. Elias Fries described a considerable number of myxomycetes in several important mycological papers during the first half of the nineteenth century. About fifteen of these species are accepted as distinct in current myxomycete literature, as are the two genera Lindbladia and Perichaena. The first comprehensive summary of Swedish myxomycetes was published by Robert Fries (1912), who listed 132 species as confirmed from Sweden. Santesson (1964) added many new records and summarized 165 species from Sweden. During the past three or four decades an additional twenty-five species have been reported in various publications and are cited below. Changes in circumscription and delimitation of taxa have affected several names in earlier published species lists.

Several additional species have been found during the ongoing inventory within the frames of the Swedish Taxonomy Initiative project. A selection of twenty species not previously reported from Sweden is presented in this paper, making a total number of 210 species herewith formally reported. Additional records are awaiting publication but several taxa require extensive taxonomic discussions. Continued field-work supplemented by moist chamber cultures will further increase the number of species known to occur in Sweden. 


\section{Summary of species reported from Sweden during the past few decades}

The following twenty-five species have been reported from Sweden after the publication of Santesson's (1964) list. Many of these species have been recorded again, some species several times, after their first published record.

Amaurochaete comata G. Lister \& Brândză (Eliasson 1977)

A. trechispora T. Macbr. \& G. W. Martin (Eliasson 2000)

Arcyria affinis Rostaf. (Schinner 1983)

A. fuegiana Aramb. (Nannenga-Bremekamp \& Schinner 1986)

A. rubrobrunnea Nann.-Bremek. \& Schinner (Nannenga-Bremekamp \& Schinner 1986)

A. verrucosituba Nann.-Bremek. \& Schinner (Nannenga-Bremekamp \& Schinner 1986)

Badhamia apiculospora (Härk.) Eliasson \& N. Lundq. (Eliasson \& Lundqvist 1979)

Collaria arcyrionema (Rostaf.) Nann.-Bremek. ex Lado (Eliasson 1975 as Lamproderma a.)

Colloderma oculatum (C. Lippert) G. Lister (Eliasson \& Sunhede 1972)

Diderma asteroides (Lister \& G. Lister) G. Lister (Eliasson 1975)

D. cingulatum Nann.-Bremek. (Eliasson 1975)

D. simplex (J. Schröt.) G. Lister (Schinner 1983)

Didymium anellus Morgan (Eliasson 1975)

Fuligo cinerea (Schwein.) Morgan (Schinner 1983)

Hemitrichia calyculata (Speg.) M. L. Farr (Eliasson 1975)

Licea belmontiana Nann.-Bremek. (Eliasson \& Lundqvist 1979)

Perichaena depressa Lib. (Eliasson 1975)

Physarum flavidum (Peck) Peck (Schinner 1983)

P. nudum T. Macbr. (Schinner 1983)

P. robustum (Lister) Nann.-Bremek. (Schinner 1983)

P. serpula Morgan (Eliasson \& Strid 1976)

Stemonaria pilosa Nann.-Bremek. (Nannenga-Bremekamp et al. 1984)

Stemonitis virginiensis Rex (Schinner 1983)

Symphytocarpus amaurochaetoides Nann.-Bremek. (Schinner 1983)

Trichia erecta Rex (Eliasson 1975).

The four Arcyria species listed had all been collected in the province of Lappland north of the Arctic circle. The records of Arcyria rubrobrunnea and $A$. verrucosituba are the type collections, so far the sole records in the world. Arcyria fuegiana represents the second record in the world, the species was previously known only from the type collection from Argentina. All four Arcyria species listed belong to the red-spored group of species several of which offer taxonomical difficulties.

\section{Selected species new to Sweden}

The following list is a selection of species not previously reported from Sweden. Records made from moist chamber cultures have been marked by "mc". Dates given for such records are dates when the substratum was collected. For species represented by numerous collections only representative specimens have been cited.

Arcyria globosa Schwein.

Västergötland: Töllsjö, on bark from living Quercus, mc, Aug 1989 Eliasson 3664 (GB); Mölndal, on bark from living Quercus, mc, May 1996 Eliasson 4952 (GB). 
Arcyria stipata (Schwein.) Lister

Närke: Hackvad, on decaying stump of Populus, Oct 1998 Nilsson (S).

Badhamia affinis Rostaf.

Västergötland: Göteborg, Kärralund, Aug. 1948, Nathorst-Windahl (GB); Istrum, Sept 2003 Lundqvist (S). Uppland: Balingsta, Oct 1987 Lundqvist 17068 (S).

\section{Comatricha ellae Härk.}

Västergötland: Alingsås, Östad Säteri, on dead wood of Quercus, mc, Apr 2007 Eliasson \& Sjögren 6675 (GB).

Comatricha longipila Nann.-Bremek.

Halland: Långavaka, on wood and bark of Quercus, mc, July 2004 Gilert \& Eliasson 6273 (GB).

Comatricha tenerrima (M. A. Curtis) G. Lister Halland: Tjolöholm, on grass, mc, Sep. 2005 Eliasson \& Gilert 6430 (GB).

Cribraria macrospora Nowotny \& H. Neubert Västergötland: Vårgårda, Klovnasten, on decaying wood, Oct 1970 Eliasson 2744 (GB); Töllsjö, on decaying wood of Picea, Oct 1992 Eliasson 4669 (GB).

This relatively recently described species (Nowotny \& Neubert 1993) is closely related to C. macrocarpa and C. argillacea in habit and ecology and grows preferably on strongly decayed wood and bark of Picea, where fruitings up to $0.25 \mathrm{~m}^{2}$ in extent have been seen.

Cribraria oregana H. C. Gilbert

Halland: Särö Västerskog, on decaying wood of Pinus, mc, May 2003 Eliasson 6034 (GB).

Diderma floriforme (Bull.) Pers.

Halland: Tjolöholm, at ground level on stump of Quercus, Sept 2005 Eliasson \& Gilert 6399 (GB). Västergötland: Göteborg, on decaying wood of Quercus, Oct 1943 Nathorst-Windahl (GB); Alingsås, on branch of Quercus on the ground, Dec 2006 Sjögren (GB).

Didymium bahiense Gottsb.

Västergötland: Alingsås, Nolhaga, on bark from living Acer, mc, Aug 2006 Eliasson \& Gilert 6610 (GB).
Echinostelium bisporum (L. S. Olive \& Stoian.)

K. D. Whitney \& L. S. Olive - Figs. 5-7

Västergötland: Mölndal, Stensjön, on dead grass, mc, Nov 2005 Gilert \& Eliasson 6510 (GB); Töllsjö, on bark from living Acer, mc, Mar 2006 Eliasson \& Gilert 6520 (GB).

With fruitbodies rarely exceeding $25 \mu \mathrm{m}$ in height and producing only two spores, this is the smallest of all myxomycetes known. The spores are shed together in characteristic dyads (Fig. 7). It was originally described as a protostelid of the genus Cavostelium (Olive \& Stoianovitch 1966) but was later transferred to Echinostelium based on convincing similarities in ultrastructure and development (Whitney et al. 1982).

Echinostelium bisporum is too small to be found using standard techniques for myxomycetes and, therefore, has mainly been recorded in studies on protostelids. It is too small to be observed in moist chamber cultures even under a high magnification stereo microscope. Although probably of worldwide distribution it is believed to be more common in warmer regions. Originally described on material from Malaysia, Sri Lan$\mathrm{ka}$ and Florida it has been reported from northern India (Shadwick \& Stephenson 2004) and been demonstrated to be at least locally abundant in Central America (Moore \& Stephenson 2003). It also seems to be a common species in Hawaii, occurring on various kinds of substrata where protostelids grow (Spiegel, pers. comm.). In Europe it has previously been verified from Germany (Tesmer et al. 2005).

Echinostelium brooksii K. D. Whitney - Figs. 1,2

Halland: Särö Västerskog, on bark from living Quercus, mc, May 2003 Eliasson 6039 (GB). Västergötland: Göteborg, on bark from living Robinia, mc, Nov 2003 Eliasson 6071, 6072 (GB); same locality and substratum, mc, Jan 2005 Eliasson 6262 (GB); Alingsås, Mjörn, on bark from dead Alnus, mc, Apr 2004 Eliasson \& Gilert 6134 (GB); Alingsås, Nolhaga, on bark from living Acer, mc, Aug 2006 Eliasson \& Gilert 6610 (GB).

Echinostelium colliculosum K. D. Whitney \& H. W. Keller

Halland: Särö Västerskog, on bark and bryophytes on bark (together with E. lunatum and E. minutum), mc, May 2003 Eliasson \& Gilert 

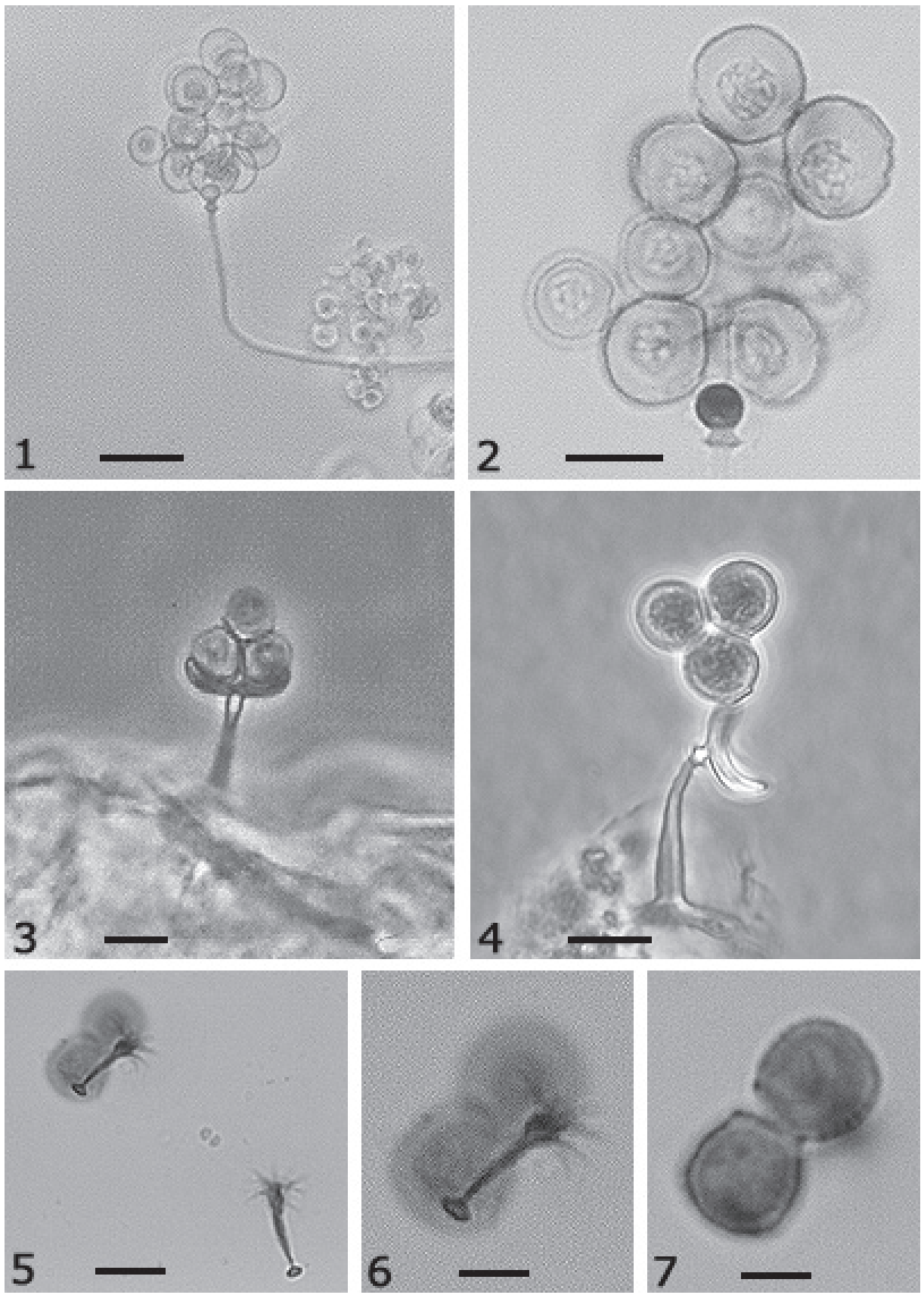

Figs. 1, 2. Echinostelium brooksii (Eliasson 6072). - 1: Fruitbody. Bar: $20 \mu \mathrm{m}$. - 2: Upper part of fruitbody further enlarged, showing spores, strongly pigmented globose columella and peridial collar below columella. Bar: $10 \mu \mathrm{m}$. - Figs. 3, 4. Echinostelium lunatum. - 3: Fruitbody with spores and crescent-shaped columella (Gilert \& Eliasson 6095b). Bar: $10 \mu \mathrm{m}$. - 4: Emptied fruitbody with columella and peridial collar below columella (Gilert \& Eliasson 6519). Spores are still attached to one another by disc-like raised wall thickenings. Bar: $10 \mu \mathrm{m}$. - Figs. 5-7. Echinostelium bisporum, specimens dyed in cotton-blue (Gilert \& Eliasson 6510). - 5: Two fruitbodies with spores shed. The columella is flattened and the stalk has rhizoid-like extensions at base. Bar: $10 \mu \mathrm{m}$. - 6: Part of preceding figure further enlarged. Bar: $5 \mu \mathrm{m} .-7$ : Same picture as in Fig. 6 but focus set at the underlying spore dyad. Bar: $5 \mu \mathrm{m}$. 
$6095 a$ (GB); Tjolöholm, on bark, mc, Sept 2005 Eliasson \& Gilert 6418 (GB).

Echinostelium fragile Nann.-Bremek.

Västergötland: Mölndal, Sisjön, on bark from living Alnus, mc, Feb 2004 Eliasson \& Gilert 6096 (GB); Alingsås, Mjörn, on bark from dead Alnus, mc, Apr 2004 Eliasson \& Gilert 6133 (GB); Göteborg, Botanical Garden, on cone of Larix on the ground, mc, Mar 2005 Eliasson \& Gilert 6310 (GB).

Echinostelium lunatum L. S. Olive \& Stoian. - Figs. 3, 4

Halland: Särö Västerskog, on bark and bryophytes on bark (together with E. colliculosum and E. minutum), mc, May 2003 Eliasson \& Gilert $6095 b$ (GB). Västergötland: Töllsjö, on bark and bryophytes on bark from living Acer, mc, Mar 2006 Eliasson \& Gilert 6519 (GB).

With fruitbodies $20-50 \mu \mathrm{m}$ in height, this is the second smallest of all myxomycetes known and normally not possible to observe even under a strongly magnifying stereo microscope. Long known only from Puerto Rico and the United States this is the first verified record from Europe. The species is likely to be far more common in the world than the few records would suggest, which probably holds for several species within the same genus.

\section{Licea biforis Morgan}

Västergötland: Göteborg, Botanical Garden, on dead herbs, mc, Mar 2005 Gilert \& Eliasson 6357 (GB); Mölndal, Gunnebo, on dead grass, mc, Nov 2005 Gilert \& Eliasson 6477
(GB); Alingsås, Östad Säteri, on dead stems of Chamaenerium, mc, Apr 2007 Eliasson \& Sjögren $6676(\mathrm{~GB})$.

Paradiacheopsis longipes Hooff \& Nann.Bremek. - Fig. 8.

Lappland: Lycksele, on twigs protruding above snow layer, mc, Apr 2005 Eliasson \& Forsberg 6359 (GB).

An easily overlooked species due to its small size, but very well defined through an excellent combination of characteristics: sporothecae 0.1 $-0.2 \mathrm{~mm}$ in diam. on long filiform stalks up to ten times the diameter of the sporotheca, stalks enclosed in a hyaline sheath, spores with widely spaced but very distinct warts.

Apart from the type collection from the Netherlands (Hooff \& Nannenga-Bremekamp 1996) this species has also been reported from China (Ukkola et al. 2001).

\section{Paradiacheopsis solitaria (Nann.-Bremek.)} Nann.-Bremek.

Halland: Särö Västerskog, on mosses and lichens on bark of living Malus, mc, Aug 2006 Eliasson 6583 (GB); Near Falkenberg, on bark, mc, July 2004 Eliasson \& Gilert 6424 (GB). Västergötland: Mölndal, Lunnagården, on bark from living Alnus, mc, Feb 2004 Eliasson 6089 (GB); Jonsered, on bark from old Tilia, mc, Sept 2005 Eliasson \& Gilert 6422 (GB); Överlida, on bark of living old Juniperus, Aug 2006 Eliasson 6587 (GB).

Apparently an overlooked but probably common species so far recorded from south-western Sweden by numerous specimens (field collec-
Fig. 8. Paradiacheopsis longipes (Eliasson \& Forsberg 6539). The diameter of the sporotheca is ca $0.2 \mathrm{~mm}$.

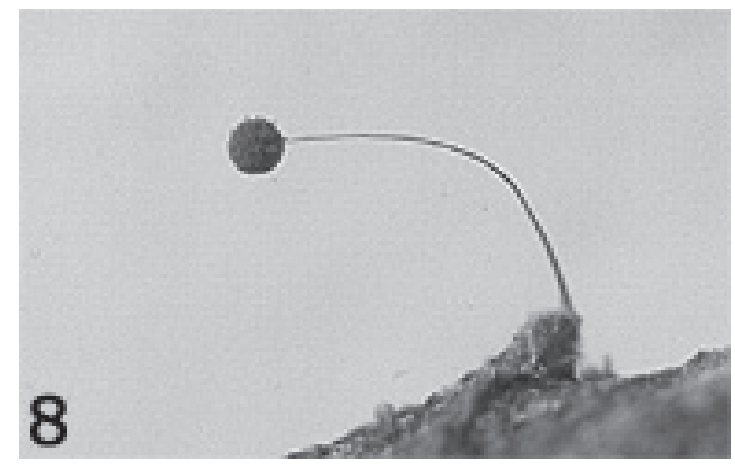


tions as well as moist-chamber cultures) on bark (and lichens and bryophytes on bark) of various living trees (Juniperus, Alnus, Malus, Populus, Tilia, Quercus).

Perichaena chrysosperma (Curr.) Lister

Halland: Särö Västerskog, on bark of living Sambucus nigra, mc, June 2003 Eliasson 6049 (GB). Västergötland: Göteborg, Askim, on bark of living Malus, mc, Aug 2003 Eliasson 6059 (GB); Göteborg, Botanical Garden, on bark of living Ulmus, mc, Oct 2003 Eliasson 6070 (GB); Töllsjö, on bark of living Fraxinus, mc, Eliasson 6561 (GB); Alingsås, Nolhaga, on bark of living Acer, mc, Oct 2006 Eliasson 6615 (GB).

Apparently a common species at least in south-western Sweden. It has been obtained numerous times in moist chamber cultures on bark from a large variety of deciduous trees. As currently accepted this is a very variable species. The material cited is rather uniform, consisting of scattered or solitary, globose or subglobose fructifications on bark or mosses on bark of living trees. The capillitium is ornamented with spinous processes rarely exceeding $2 \mu \mathrm{m}$ in length. These specimens are quite different from specimens from tropical and subtropical areas where fructifications are typically plasmodiocarpous, commonly arcuate or ring-shaped, and the capillitium has spines up to $6 \mu \mathrm{m}$ long. The different forms were exhaustively discussed by Keller (1971) and incorporated within the same species. The differences are nowadays attributed to ecotypic variation.

Physarum squamosum L. Flatau \& P. Schirmer Västergötland: Mölndal, vicinity of Lake Sisjön, on bark of fallen decaying stem of Populus tremula, Oct 2001 Eliasson 5777, $5778 b$ (GB).

This species is characterized by globose sporothecae $0.5-0.7 \mathrm{~mm}$ in diameter on thick black stalks and the peridium covered with prominent whitish calcium tubercles which are brownish in the centre. It was described from Germany (Flatau \& Schirmer 2004) on dead twigs of Sambucus and bark of living Populus. Two specimens (in GB) from U.S.A., (Kentucky, on dead branches of Juniperus virginiana, T. E. Brooks 2806; Iowa, on bark of living Fraxinus americana, H. W. Keller 1020), bear an unpublished specific epithet, "tuberculatum", obviously referring to the prominent ornamentation of the peridium.

\section{Discussion}

The publication of the world monograph of myxomycetes by Martin and Alexopoulos in 1969 was a great stimulus to further studies of these organisms, which has resulted in an increasing number of publications and descriptions of new species during the past few decades. This trend is likely to continue although better understanding of the biological system of these organisms and the influence of environmental conditions on the structure of the fruitbodies will probably warrant modified circumscriptions of several species and reduce several published names to synonyms.

The general adoption of the moist-chamber technique, where a piece of a suitable substratum is placed under favourable ambient conditions in a petri dish, has strongly contributed to the number of new species described during the past few decades. This technique allows species with minute and fragile fruitbodies to develop more or less protected from various arthropods and other disturbing factors, and has demonstrated the presence of a number of species too small to be observed in the field. As a consequence, proportionally more species have been described during recent decades in genera with minute fruitbodies, such as Licea and Echinostelium, than in genera with larger fruitbodies. In Martin and Alexopoulos (1969) four species of Echinostelium were accepted (apart from E. roseum which was later proved not to belong here), whereas Lado (2001) lists fourteen species. Additional species are likely to be found. This paper reports five species of Echinostelium new to Sweden, all found in moist chamber cultures. At least three additional species of this genus are likely to be found here.

It is difficult to get a true picture of the distribution of organisms that are so small that they cannot be seen with the naked eye. There is a general tendency for minute organisms to be more widespread the smaller they are. Many species represented by a single or a few records are probably far commoner than the number of records would suggest. This certainly holds for many small myxomycetes where there are several examples where a species long known from only the type collection or from only one part of the world may unexpectedly be found in a new locality very distant from previous records, not rarely on a new continent. There is no reason to believe that, for example, Paradiacheopsis lon- 
gipes would be as rare as the widely separate records from Europe and China would hint. It simply is too small to be easily seen, even with a hand lens, and is likely to be found, perhaps worldwide, where conditions are suitable. Echinostelium bisporum and E. lunatum are even better examples where size itself excludes detection. For recording such minute fruitbodies methods used for protostelids have to be applied (Moore \& Spiegel 1995, Tesmer et al. 2005).

One of the most interesting Swedish records reported during the past few decades is that of Arcyria fuegiana from north of the Arctic circle (Nannenga-Bremekamp \& Schinner 1986). As already mentioned this is the second record in the world, the species being known previously only from the type collection from Tierra del Fuego in southern Argentina (Arambarri 1972). We have not seen any material of this species. Nevertheless, the records give a clear hint not only that further field-work is needed in the northern alpine areas of Sweden, but also that the distribution patterns and morphological variation of the red-spored Arcyria species are incompletely understood. This is further corroborated by the two likewise red-spored species $A$. rubrobrunnea and $A$. verrucosituba, both known only from their respective type collections from north of the Arctic circle.

As already mentioned, this paper brings the total number of myxomycete species known to Sweden to 210 but several records remain to be published. Although an inventory will never be complete the rising curve of number of species in Sweden is likely to level off perhaps somewhere around 230. The northern alpine areas are still insufficiently studied. A few so-called nivicolous myxomycetes, species developing fruitbodies under or close to melting snow, have been recorded, but considering the large number of species of this ecological group known from other parts of Europe, Sweden's alpine region can be expected to harbour several nivicolous species of genera such as Diderma, Lamproderma and Lepidoderma yet to be recorded.
Acknowledgements: We are grateful to Dr. Grazina Adamonyte and Mr. David Mitchell for valuable and constructive comments on an earlier version of the manuscript. Their points of view significantly improved the paper.

\section{References}

Arambarri, A. M. 1972: Una nueva especie de Myxomycetes de Tierra del Fuego (Argentina). - Bol. Soc. Argent. Bot. 14: 154-156.

Eliasson, U. 1975: Myxomycetes in the Nature Reserve of the Gothenburg Botanical Garden. - Sv. Bot. Tidskr. 69: 105-112.

Eliasson, U. 1977: Ecological notes on Amaurochaete Rost. (Myxomycetes). - Bot. Notiser 129: 419-425.

Eliasson, U. H. 2000: Observations on the genus Amaurochaete (Myxomycetes), and a European record of A. trechispora. - Karstenia 40: 31-38.

Eliasson, U. \& Lundqvist, N. 1979: Fimicolous myxomycetes. - Bot. Notiser 132: 551-568. Eliasson, U. \& Strid, A. 1976: Wood-inhabiting fungi of alder forests in North-Central Scandinavia. 3. Myxomycetes. - Bot. Notiser 129: 267-272.

Eliasson, U. \& Sunhede, S. 1972: Some Swedish records of Myxomycetes. - Sv. Bot. Tidskr. 66: 18-24.

Flatau, L. \& Schirmer, P. 2004: Neue Myxomyceten aus Deutschland. - Zeitschrift für Mykologie 70: 187 206.

Fries, R. E. 1912: Den svenska myxomycet-floran. - Sv. Bot. Tidskr. 6: 721-802.

Hooff, J. P. M. van \& Nannenga-Bremekamp, N. E. 1996: Additions to the Myxomycetes of the Netherlands. Proc. Kon. Nederl. Akad. Wet., Ser. C, 99: 45-53.

Keller, H. W. 1971: The genus Perichaena (Myxomycetes): a taxonomic and cultural study. - Thesis PhD, University of Iowa, May 1971.

Lado, C. 2001: Nomenmyx, a nomenclatural taxabase of myxomycetes. - Cuad. Trab. Flora Micol. Ibér. 16.

Martin, G. W. \& Alexopoulos, C. J. 1969: The Myxomycetes. University of Iowa Press.

Moore, D. \& Spiegel, F. W. 1995: A new technique for sampling protostelids. - Mycologia 87: 414-418.

Moore, D. \& Stephenson, S. 2003: Microhabitat distribution of protostelids in a tropical wet forest in Costa Rica. - Mycologia 95: 11-18.

Nannenga-Bremekamp, N. E. \& Schinner, F. 1986: Notes on some species of Arcyria (Myxomycetes). - Proc. Kon. Nederl. Akad. Wet., Ser. C, 89: 327-334.

Nannenga-Bremekamp, N. E., Yamamoto, Y. \& Sharma, R. 1984: Stemonaria, a new genus in the Stemonitaceae and two new species of Stemonitis (Myxomycetes). - Proc. Kon. Nederl. Akad. Wet., Ser. C, 87: 449-469.

Nowotny, W. \& Neubert, H. 1993: Cribraria macrospora Nowotny \& Neubert n. sp. In: Neubert, H., Nowotny, W. \& Baumann, K., Die Myxomyceten Deutschlands und des angrenzenden Alpenraumes unter besonderer Berücksichtigung Österreichs. Bd 1. Karlheinz Baumann Verlag, Gomaringen.

Olive, L. S. \& Stoianovitch, C, 1966: A new two-spored species of Cavostelium (Protostelida). - Mycologia 58: $440-451$. 
Santesson, R. 1964: Swedish Myxomycetes. - Sv. Bot. Tidskr. 58: 113-124.

Schinner, F. 1983: Myxomycetes aus dem Gebiet des Torne Träsk (Abisko) in Schwedisch Lappland. - Sydowia, Ann. Mycol. 36: 269-276.

Shadwick, J. \& Stephenson, S. 2004: First records of protostelids from northern India. - Fungal Diversity 16: 141-145.
Tesmer, J., Rulik, B., Spiegel, F., Shadwick, J. \& Schnittler, M. 2005: Protostelids from German beech forests. - Mycol. Progr. 4: 267-271.

Ukkola, T., Härkönen, M. \& Zeng, Z. 2001: Myxomycetes of Hunan Province, China. I. - Ann. Bot. Fennici 38: 305-328.

Whitney, K. D., Bennett, W. E. \& Olive, L. S. 1982: Observations on Echinostelium bisporum. - Mycologia 74: 677-680. 